\title{
Reimaging the role of the information professionals in the Educational process: the case of the Sultanate of Oman
}

\author{
Prof. Naeema Jabur
}

\author{
Dr. Rahma Alkharousi
}

\begin{abstract}
This research applied a mixed-approach to investigate professionals perceive on their profession and what others expect from them to lead professional organizations setting their core competencies for the future. Furthermore, the research aimed to explore LRCs observes their educational preparation and job practices in building their profession. Besides, it defines the critical restrictions that prohibit them from reimaging their future professional roles within the educational process. Questionnaires are used to explore Omani professionals acquired competencies from learning and work. In addition, the research conducted tow discussion sessions with 10 focus groups to support the quantitative data collected through questionnaires. The quantitative findings indicated that a weak correlation between educational programs and work practices, especially in tasks requiring specialized skills and competencies. The qualitative findings highlighted the Competencies acquired by the information professional from work which are public relations, research skills, and partnership, marketing services skills, dealing with technology, and ways of dealing with the beneficiary. Besides, the findings revealed skills needed by the learning resource specialists as training in updating developments in the field, English language. Negative School staff's view information profession as multifunction of tasks that are not directly attributed to their occupation as well as far from the LRC regulations. The lack of communication between information professionals and supervisors, the absence of the learning resource specialists at schools in the first cycle of the basic education, the weakness of maintenance of hardware and Internet in schools, incorrect Job Title which is LRC Resource Specialist, are challenges hindered Omani professionals to make improvements in their profession. Accordingly, findings present suggestions to improve the actual status.
\end{abstract}

Keywords: Omani information professionals, Omani schools, Information as a multidisciplinary field

\section{INTRODUCTION}

Without any suspect, it is clear that the driving force behind educational reformation in any country is technological development. Thus, every educational system intends to enable the school's community to become technologically cultured in communication, learning, teaching, and information seeking behavior. Markaz al-Imarat li-al-Dirasat wa-al-Buhuth (2013) emphasized the role of the information communication technology as a pillar for change in that "more and more people involved in the educational process accept the notion that ICT has become part of our everyday life, and recognize the value of ICT as an enhancer for teaching and learning." Consequently, countries such as the Sultanate of Oman considered the transformation from preliminary to basic education as a constructive step followed by introducing the Resource Learning Centers (RLC) as substitutes to school libraries. This transformation was directed to integrate the educational process with the extracurricular activities to match future needs with the comprehensive development of the country. From the RLC side, the Ministry of Education submits great efforts for restructuring the centers and their 
policies to achieve the transformation process. Accordingly, the developments had an impact on the competencies and skills required by resource learning professionals to fulfill their new roles' requirements.

It is the aim of this study to explore the status of the currently activated competencies and skills from the perspectives of the Resource-Learning Professionals (RLPs). Moreover, the study anticipated investigating the role of both the educational preparation and job practices in developing these competencies and to sightsee the restrictions for re-imaging their future roles and limiting their self-development at work.

\section{Purposes and research questions}

The study intends to respond to the following questions for achieving the above aims of the study, including

1- How do RLPs in Oman perceive their current professional image?

2- How do RLPs observe their educational preparation and job practices in building their profession?

3- What are the critical restrictions that prohibit RLS from reimaging their future professional roles within the educational process?

4- : How do RLPs assess the competencies they acquired from both education and job practices at work?

5- Is there a correlation between their perspectives towards the contributions of education and job practices in building their competencies?

\section{LITERATURE REVIEW}

A Professional image can be generated according to a set of characteristics perceived by others i.e., users, supervisors, communities, etc.) However, professionals themselves might formulate an image they wanted to have others look through them to their profession. That image builds on their accumulated knowledge from education, experience and training. The conflict between what professionals perceive on their profession and what others expect from them lead professional organizations to set the core competencies. They intend to characterize the professional image. The sets of competencies have been recognized and modified based on observing the required skills and comprehensive communication and technological development. This is, of course, is considered a healthy process to judge the status and importance of the profession.

Updating the established competencies always linked to a variety of factors. Stark (2005) found that professional behavior can be deliberated to theories about required competencies. He emphasized, "People are constantly observing your behavior and forming theories about your competence, character, and commitment." Hashim and Mokhtar, (2012) underlined that the changes in the new information environment have an impact on the role, job, opportunities, self-image and survival of information professionals. These changes imply new skills and abilities to understand and use information. Australian Library and Information Association (2014) is more optimistic about the future of librarians. The Association focused on the culture of shared knowledge and information technology that turns the role of professionals to "become the solvers of problems automated systems like Google cannot solve." Moreover, the Association suggested linking information management to information technology to make the profession as "strong brands in the public eye". Ruddock (2012) took into account the impact of socializing with users as being the main key to working in a professional services environment." He stressed on the need to know what makes users stick to the services professionals are providing. 
Despite the considering the above factors in developing the core competencies required to shape the profession, there is no agreement in defining the word competency itself. Ennis, (2008) and Ley and Albert (2003) defined competencies as being the needed characteristics from an individual to succeed in his role or to demonstrate greater performance. Athey and Orth, (1999) added another characteristic to the definition of competencies in that they must be observable and measurable to add value. While Kang and Ritzhaupt (2015); Moore and Rudd (2004) and Ley and Albert (2003) focused on core skills, including knowledge, skills, attitudes and attributes to constitutes the professional competencies.

The question that can be arisen here is what skills and knowledge have to be considered about Librarians and information professionals' competencies? Who is responsible for constituting these required skills and knowledge to fulfill the needed competencies? In other word, Hashim and Mukhtar (2012) formalize the question from the educational responsibilities. They stated, "How does the library school or faculty prepare the librarians to meet job market that is demanding, constantly changing, challenging with many diversified needs." ARMA International (2007) stressed that the required competencies to "move the focus from "what" an employee must accomplish (defined in the typical job description) to "how" the employee accomplishes the required tasks." Canadian General Standards Board (2009) and the Association of Canadian Archivists (2017) emphasized on the skills, abilities and behaviors that enable professionals to achieve results as well as Lifelong Learning and Professional Success. While the American Association of Law Libraries (2001) perceived them pillars to accomplish their professional and occupational tasks successfully. Besides, the Association stressed the role of both continuing education and experience in shaping these competencies. For more specifically consideration, the Special Library Association (SLA) issued the updated "Competencies for information professionals of the 21st century" in 2016. Within This issue, SLA defined professional competencies as " the practitioner's knowledge of information resources, access, technology and management, and the ability to use this knowledge as a basis for providing the highest quality information services" (Special Libraries Association (SLA), 2003, p. 2).

Fraser-Arnott, M. (2017) emphasized that the motives behind the establishment of the observable and measurable sets of competencies are to acknowledge the multi-roles librarians and information professionals are playing within the current changeable environment. In order to prepare the professionals for the multi-roles, we should recognize what sets of competencies they need to be able to function in managing records, information and knowledge. Moreover, in the educational discipline, as much more focus is given to how learners "can use their learning to solve problems, perform procedures, and communicate effectively," more educational and communicational skills have been added to focus on the result of education rather than on what and how to learn (Gruppen, Mangrulkar, and Kolars, 2012). This led to the movement from focusing on collection building and management to information accessibility and management. Furthermore, such consideration led to "a reflection on policies regarding the education of information professionals" (Ferreira \& others, 2007). They judged that, for information professionals to perform successfully in the new wide information spaces, policies regarding the educational and training programs must consider appropriate core competencies.

In conclusion, competencies intend to provide a clear image of a profession through an organized, observable and measurable set of skills, characteristics and qualities. Continues updating of these competencies will reimage the profession to match it with job market needs and the work environment. However, knowledge engagement between education and 
experience is necessary to reshape and fully develop the required role of the profession and to approve the nonstop need for it in the job market.

\section{METHODOLOGY}

A mixed approach, qualitative and quantitative, was applied to respond to search questions. The quantitative part is designed to identify the competencies gained from education and job practices at work from the professionals' perspectives themselves. The Chartered Institute of Library and Information Professionals (CILIP) list of competencies was selected for measuring the level of the accomplished competencies. The judgment for such selection is that the Department of Information Studies, the major professional department in Oman, obtained the academic accreditation for its programs from CILIP in 2015. The following research questions were tested:

1: How do RLPs assess the competencies they acquired from both education and job practices at work?

2: Is there a correlation between their perspectives towards the contributions of education and job practices in building their competencies?

A qualitative method was collected using the focus group discussions. This method of data collection was intended to provide more in-depth information about the information professionals' attitudes and perspectives regarding the role of the information professionals in the Educational process. Moreover, it helped in exploring the information professionals' suggestions regarding the role of the information professionals in the Educational process in the Sultanate of Oman. Semi-structured questions were used to investigate reimaging the role of the information professionals in the Educational process. This tool is a flexible means of asking in-depth questions and clearing up any misunderstandings. Analyses of these questions have been used to develop a rich picture to describe the situation of current professional image and identify the factors affecting their educational preparation and job practices in building their profession. The focus group included the following basic questions:

1- How do RLPs in Oman perceive their current professional image?

2- How do RLPs observe their educational preparation and job practices in building their profession?

3- What are the critical restrictions that prohibit them from reimaging their future professional roles within the educational process?

The focus group discussion results are presented according to the thematic approach.

\section{Part A: Results of the quantitative data:}

\section{DATA ANALYSIS}

To test the quantitative research questions, a sample of (29) Resource Learning Specialists (their job title) were asked to assess the level of skills they received from education and job practices at work. Data analysis will respond to the research questions as follows:

Research Question 1: How do RLPs assess the competencies they acquired from both education and job practices at work?

The overall average of the professionals' assessment of the obtained competencies from education and work has been calculated and compared against every individual competency. It is found that the overall average of the acquired competencies from education is 1.8 and 1.7 from work out of maximum level 3. Seven out of 12 competencies counted above the average from education and only two from work. Research skill was considered as the most acquired skill from education while customer focus and IT and communication are measured to be the highest skills acquired from work. Table (1) and Figure (1) for more details. 


\section{Table -1- an average of acquired competencies from education and work}

\begin{tabular}{|c|c|c|c|c|c|c|c|c|c|c|}
\hline \multirow[t]{2}{*}{ Competencies } & \multirow{2}{*}{$\begin{array}{l}\text { General } \\
\text { Average } \\
\text { from } \\
\text { learning }\end{array}$} & \multirow{2}{*}{$\begin{array}{c}\text { General } \\
\text { Average } \\
\text { from } \\
\text { work }\end{array}$} & \multicolumn{2}{|c|}{$\begin{array}{l}\text { Below the } \\
\text { Average } \\
\text { (Learning) }\end{array}$} & \multicolumn{2}{|c|}{$\begin{array}{l}\text { Above the } \\
\text { Average } \\
\text { (Learning }\end{array}$} & \multicolumn{2}{|c|}{$\begin{array}{l}\text { Below the } \\
\text { Average } \\
\text { (Working) }\end{array}$} & \multicolumn{2}{|c|}{$\begin{array}{l}\text { Above the } \\
\text { Average } \\
\text { (Working) }\end{array}$} \\
\hline & & & $\#$ & $\%$ & \# & $\%$ & \# & $\%$ & & \\
\hline Organizing & 2.1 & 1.4 & 10 & 34.5 & 19 & 65.5 & 14 & 48.3 & 15 & 51.7 \\
\hline & 2 & 15 & 14 & 483 & 15 & 517 & 12 & 414 & 17 & 586 \\
\hline $\begin{array}{l}\text { Using and } \\
\text { exploiting } \\
\text { knowledge and } \\
\text { information } 2.11\end{array}$ & 2.2 & 1.5 & 12 & 41.4 & 17 & 58.6 & 13 & 44.8 & 14 & 55.2 \\
\hline Research Skills & 2.3 & 1.3 & 16 & 55.2 & 13 & 44.8 & 14 & 48.3 & 15 & 51.7 \\
\hline $\begin{array}{l}\text { Information } \\
\text { Governance and } \\
\text { Compliance }\end{array}$ & 2 & 1.4 & 13 & 44.8 & 16 & 55.2 & 12 & 41.4 & 17 & 58.6 \\
\hline $\begin{array}{l}\text { Records } \\
\text { Management and } \\
\text { Archiving }\end{array}$ & 1.9 & 1.9 & 15 & 51.7 & 14 & 48.3 & 13 & 44.8 & 16 & 55.2 \\
\hline $\begin{array}{l}\text { Collection } \\
\text { Management and } \\
\text { Development }\end{array}$ & 2.1 & 1.5 & 15 & 51.7 & 14 & 48.3 & 12 & 41.4 & 17 & 58.6 \\
\hline $\begin{array}{l}\text { Literacies and } \\
\text { Learning }\end{array}$ & 1.8 & 2 & 15 & 51.7 & 14 & 48.3 & 12 & 41.4 & 17 & 58.6 \\
\hline $\begin{array}{l}\text { Leadership and } \\
\text { Advocacy }\end{array}$ & 1.3 & 2 & 16 & 55.2 & 13 & 44.8 & 11 & 37.9 & 18 & 62.1 \\
\hline $\begin{array}{l}\text { Strategy, Planning } \\
\text { and Management }\end{array}$ & 1.3 & 1.5 & 12 & 44.8 & 17 & 55.2 & 14 & 48.3 & 15 & 51,7 \\
\hline $\begin{array}{l}\text { Customer Focus, } \\
\text { Service Design and } \\
\text { Marketing }\end{array}$ & 1.4 & 2.1 & 15 & 51.7 & 14 & 48.3 & 14 & 48.3 & 15 & 51,7 \\
\hline $\begin{array}{l}\text { IT and } \\
\text { Communication }\end{array}$ & 1.8 & 2.1 & 13 & 44.8 & 16 & 55.2 & 13 & 44.8 & 16 & 55.2 \\
\hline $\begin{array}{l}\text { The Overall mean } \\
\text { of the } \\
\text { competencies }\end{array}$ & 1.8 & 1.7 & & & & & & & & \\
\hline
\end{tabular}

Figure -1- Mean Average of acquired competencies from learning and Work

From Learning

From Work

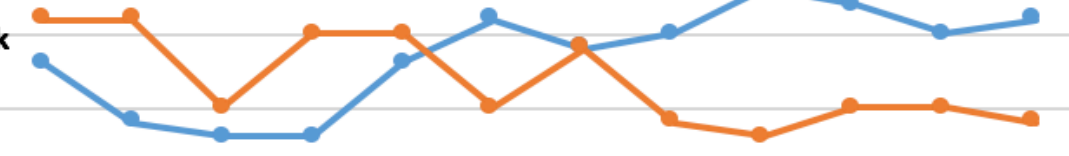

\begin{tabular}{|c|c|c|c|c|c|c|c|c|c|c|c|c|}
\cline { 2 - 12 } & $\begin{array}{c}\text { IT\& } \\
\text { Com }\end{array}$ & $\begin{array}{c}\text { Custo } \\
\mathrm{m}\end{array}$ & Plann Leader & $\begin{array}{c}\text { Literac } \\
\text { i }\end{array}$ & Collect & $\begin{array}{c}\text { Recor } \\
\text { ds }\end{array}$ & $\begin{array}{c}\text { Gover } \\
\text { n }\end{array}$ & $\begin{array}{c}\text { Resear } \\
\text { ch }\end{array}$ & Using & Know & Organ \\
\hline - Series1 & 1.8 & 1.4 & 1.3 & 1.3 & 1.8 & 2.1 & 1.9 & 2 & 2.3 & 2.2 & 2 & 2.1 \\
\hline - Series2 & 2.1 & 2.1 & 1.5 & 2 & 2 & 1.5 & 1.9 & 1.4 & 1.3 & 1.5 & 1.5 & 1.4 \\
\hline
\end{tabular}


Moreover, Table (2) presents the list of competencies arranged according to their level of education and work attainments, from the professionals' perspectives.

Table -2- The acquired competencies according to their level of attainment

\begin{tabular}{|c|c|c|c|c|c|}
\hline $\begin{array}{l}\text { Ranking Competencies } \\
\text { by Learning }\end{array}$ & $\begin{array}{l}\text { Average } \\
\text { From } \\
\text { Learning }\end{array}$ & Note & $\begin{array}{l}\text { Ranking } \\
\text { Competencies } \\
\text { By Working } \\
\end{array}$ & $\begin{array}{c}\text { Average } \\
\text { from } \\
\text { Work }\end{array}$ & Note \\
\hline Research Skills & 2.3 & \multirow{7}{*}{$\begin{array}{l}\text { Above } \\
\text { the } \\
\text { Average }\end{array}$} & $\begin{array}{l}\text { IT and } \\
\text { Communication }\end{array}$ & 2.1 & \multirow{5}{*}{$\begin{array}{l}\text { Above } \\
\text { the } \\
\text { Average }\end{array}$} \\
\hline $\begin{array}{l}\text { Using and exploiting } \\
\text { knowledge and } \\
\text { information }\end{array}$ & 2.2 & & $\begin{array}{l}\text { Customer Focus, } \\
\text { Service Design and } \\
\text { Marketing }\end{array}$ & 2.1 & \\
\hline $\begin{array}{l}\text { Organizing Knowledge } \\
\text { and Information }\end{array}$ & 2.1 & & $\begin{array}{l}\text { Literacies and } \\
\text { Learning }\end{array}$ & 2 & \\
\hline $\begin{array}{l}\text { Collection Management } \\
\text { and Development }\end{array}$ & 2.1 & & $\begin{array}{l}\text { Leadership and } \\
\text { Advocacy }\end{array}$ & 2 & \\
\hline $\begin{array}{l}\text { Knowledge and } \\
\text { Information } \\
\text { Management } \\
\end{array}$ & 2 & & $\begin{array}{l}\text { Records } \\
\text { Management and } \\
\text { Archiving }\end{array}$ & 1.9 & \\
\hline $\begin{array}{l}\text { Information Governance } \\
\text { and Compliance }\end{array}$ & 2 & & $\begin{array}{l}\text { Collection } \\
\text { Management and } \\
\text { Development }\end{array}$ & 1.5 & \multirow[t]{7}{*}{$\begin{array}{l}\text { Below } \\
\text { the } \\
\text { Average }\end{array}$} \\
\hline $\begin{array}{l}\text { Records Management } \\
\text { and Archiving }\end{array}$ & 1.9 & & $\begin{array}{l}\text { Knowledge and } \\
\text { Information } \\
\text { Management }\end{array}$ & 1.5 & \\
\hline Literacies and Learning & 1.8 & \multirow{2}{*}{$\begin{array}{l}\text { Within } \\
\text { the } \\
\text { Average }\end{array}$} & $\begin{array}{l}\text { Strategy, Planning } \\
\text { and Management }\end{array}$ & 1.5 & \\
\hline IT and Communication & 1.8 & & $\begin{array}{l}\text { Using and } \\
\text { exploiting } \\
\text { knowledge and } \\
\text { information }\end{array}$ & 1.5 & \\
\hline $\begin{array}{l}\text { Customer Focus, Service } \\
\text { Design and Marketing }\end{array}$ & 1.4 & \multirow[t]{3}{*}{$\begin{array}{l}\text { Below } \\
\text { the } \\
\text { Average }\end{array}$} & $\begin{array}{l}\text { Organizing } \\
\text { Knowledge and } \\
\text { Information }\end{array}$ & 1.4 & \\
\hline $\begin{array}{l}\text { Leadership and } \\
\text { Advocacy }\end{array}$ & 1.3 & & $\begin{array}{l}\text { Information } \\
\text { Governance and } \\
\text { Compliance }\end{array}$ & 1,4 & \\
\hline $\begin{array}{l}\text { Strategy, Planning and } \\
\text { Management }\end{array}$ & 1.3 & & Research Skills & 1,3 & \\
\hline
\end{tabular}

\section{Research Question 2: Is there a correlation between their perspectives towards the contributions of education and job practices in building their competencies?}

To measure the degree of association between the total acquired competencies from education and work, a Bivariate Correlation test was applied and the results should a significant correlation between the overall acquired competencies from education work. (0.006) at the (0.01) level. In contrast, the individual tests of several competencies did not show any significant correlation, including Organizing Knowledge and Information, Knowledge and Information Management, Using and exploiting knowledge and information, Research Skills, Collection Management and Development, Literacies and Learning, Leadership and Advocacy, Customer Focus, Service Design and Marketing. This result is consistent with the findings of 
Jabur's result that "specialized professional roles are mostly distributed within regulations rather than job description ... [and that] roles such as being a learning partner, research consultant, communication mediator and social networking facilitator are not clearly identified." (Jabur, 2017). See table 3 below.

Table -3- Results of correlation between competencies acquired from education and work

\begin{tabular}{|c|c|c|c|c|c|c|c|c|c|c|c|c|}
\hline \multirow{3}{*}{$\begin{array}{l}\text { Work } \\
\text { Sig. from correlati } \\
\text { education }\end{array}$} & on tes & etwe & $\mathrm{com}$ & tenci & s acqui & ed from & & n and & vork & & & \\
\hline & \multicolumn{12}{|c|}{$\begin{array}{l}\text { n test } \\
\text { Work }\end{array}$} \\
\hline & Org & Kno & Use & Rese & Info & Recor & Coll & Litrec & Lead & plan & Cust & IT \\
\hline $\begin{array}{l}\text { Organizing } \\
\text { Knowledge and } \\
\text { Information }\end{array}$ & .825 & & & & & & & & & & & \\
\hline $\begin{array}{l}\text { Knowledge and } \\
\text { Information } \\
\text { Management }\end{array}$ & & .156 & & & & & & & & & & \\
\hline $\begin{array}{l}\text { Using and } \\
\text { exploiting } \\
\text { knowledge and } \\
\text { information }\end{array}$ & & & .146 & & & & & & & & & \\
\hline Research Skills & & & & .573 & & & & & & & & \\
\hline $\begin{array}{l}\text { Information } \\
\text { Governance and } \\
\text { Compliance }\end{array}$ & & & & & .000 & & & & & & & \\
\hline $\begin{array}{l}\text { Records } \\
\text { Management } \\
\text { and Archiving }\end{array}$ & & & & & & .018 & & & & & & \\
\hline $\begin{array}{l}\text { Collection } \\
\text { Management } \\
\text { and } \\
\text { Development }\end{array}$ & & & & & & & .813 & & & & & \\
\hline $\begin{array}{l}\text { Literacies and } \\
\text { Learning }\end{array}$ & & & & & & & & .056 & & & & \\
\hline $\begin{array}{l}\text { Leadership and } \\
\text { Advocacy }\end{array}$ & & & & & & & & & .394 & & & \\
\hline $\begin{array}{l}\text { Strategy, } \\
\text { Planning and } \\
\text { Management }\end{array}$ & & & & & & & & & & .033 & & \\
\hline $\begin{array}{l}\text { Customer } \\
\text { Focus, Service } \\
\text { Design and } \\
\text { Marketing }\end{array}$ & & & & & & & & & & & .313 & \\
\hline $\begin{array}{l}\text { IT and } \\
\text { Communication }\end{array}$ & & & & & & & & & & & & .0376 \\
\hline
\end{tabular}

\section{Part B: Results of the qualitative data:}

This part presents the thematic data analysis results. Four main themes emerged from the analysis. The first theme discusses school staff view to the information professionals. The second theme relates to competencies acquired by the information professional from work. The third theme is around skills needed by the learning resource specialists. The fourth theme presents suggestions to improve the actual status. 


\section{School staff view to the information professionals \\ The school administration}

"Learning resource specialists are considered by the school community as the less active staff who are not supervised by the school administration, and most marginalized in some context. However, the school administration used to burden them with extra works and give them more responsibilities towards particular tasks." In the following groups, G 2, 4, 5, 7, and 8 stated some of these tasks, such as "external rotation, test control and excessive reserve".

The groups also explained this view by saying "The absence of the real role of the Learning Resource Center (LRC). It is considered as a normal classroom, a place for meetings and conducting lectures "G2, 4, 6, 7 and 8. Moreover, G9 emphasized that "The unclear image on the role performed by learning resource specialists within the policy of the school administration". It confirmed that this inaccurate understanding of Learning resource specialists 'tasks led to "Dealing with the Learning Resource Center as a shopping library and considering the Learning resource specialist as a technician whose main tasks are preparing archives for administrators, teachers, copying activities and other library work."

\section{Teachers}

Teachers consider the learning resource specialists `work as "the lucky and easiest work at school because of their comfortable work". The groups also discussed "the necessity to change the teachers' perception of learning resource specialists, and the fact that most teachers depend on themselves to learn how to use educational devices. Teachers must change their view on the learning resource specialists that they are not technicians"G2.

\section{Students}

The students look at the learning resource specialists as "inferior and ambiguous image, and they focus on their teachers, despite the attempts of the learning resource specialists to get more closer to them by trying to understand constantly their needs from the center "G2. To deal with this situation, the participating groups suggested that there is a real need to improve the relationship between students and the learning resource specialists and teachers must cooperate with the learning resource specialists in" prevailing the culture of conducting scientific research among the students and assigning a specific grade to the students 'assessments and the adopted the method in their research work as well as the completion of the designated researches and reports, such as the use of the six major skills" G1,5. Group3 stressed that cooperation must be incorporated and established to show the primary role of the learning resource specialists by " the learning resource specialists are the pillars of the learning process and resources and should support the educational process and developing the learning resource for specialists and playing a vital role in the knowledge management and a key provider for it not only in the school community but in the external community as well".

\section{The learning resource specialists view regarding their career}

The learning resource specialist encounters a range of challenges; the most vital one is multifunction of tasks that are not directly attributed to him/her and not related to his/her occupation. This has led to the scattering of the learning resource specialist among these work responsibilities and neglecting the basic work of his/her profession in the LRC. For example, G1 confirmed that, " the learning resource specialist is trying hard to know all his functions but because of the multifunction of his/her job that cause failure in achieving designated tasks at work and abandon the professional core functions at the center the learning resource specialist also faces another challenge of "excluding his/her participation in making the school policy and being not involved in the development process and other school operational plans" $(\mathrm{G} 3, \mathrm{G} 4)$. 
Relationship of the LRC regulation to a misconception of its role in the school community and in the environment surrounding the school

The Learning Resource Centers `regulations (LRC) also contributed to "blurring of the real role and actual practice of the learning resource specialist"G5. As indicated by G6 and 8 "they deal with us according to the existing job description, which consists of being placing him /her on a reserve, rotation, monitoring, involvement in all committees' in particular administrative work". As an example of the negative effects of the ambiguous actual role of the LRC in the school, "using the LRC for other purposes than what was designated for as in the data entry, grades access, as system room and monitoring" G6. In addition, G7 brought up that "there is no clear job description of the information professional's tasks. He/she is sometimes considered as administrative staff, and sometimes as a technician and also as a media coordinator". Furthermore, G9 illustrated that the career description has some problems because of the lack of awareness and less understanding of the role played by the information professional at school "the tasks designated for the information professional in his/her job description are general points that are undertaken by the school's management, and this varies from one school prior to another". G9 clarified that "there is an issue in the job description which is 'Performed any other duties assigned by the authorized person ".

Besides, participants in the workshops also emphasized the fact that they are hoping in the near future to see "a clear policy of their duties; this policy will aim to focus on the role of the information professionals, and that they played a vital role as knowledge makers" G7, 8. Group 9 also confirmed that they were aspiring to see "the clarity of the provisions of the Guide on the functions of the information professional, and not as a specialist of the learning resource and the direct responsibility for it.The information professionals have to know clearly the functions of information professionals".

However, Ma and Stahl (2018) stated that students obtain better information literacy instruction through their problem-based classroom learning when instructors allow librarians full access to the courses and present librarians to the students to integrate them into the learning environment. This situation leads to instruction has become more about teaching selfsufficiency than serving as a gatekeeper of information. The partnerships developed between medical instructors and librarians contributing to sharing Liberians to curricular instructional design and learning theory development. The findings show that health sciences librarians are often expected to attend curriculum committee meetings and reach out to students both within and outside the classroom. They emphasized that librarians can play critical roles in developing course competencies and sharing them with other instructors (Ma and Stahl, 2018).

\section{Communication Between The Information Professional And The Concerned Parties}

The groups involved in the study also emphasized the lack of communication between information professionals and supervisors "The lack of communication between the supervisor, the first supervisor, the administrative supervisor and the resident supervisor regarding the responsibilities of the information professionals"G5. This negatively affects the quality of the performance of the school's learning process according to the views of the participants in the workshops. As demonstrated by G7 "there is no transparency in communication with the Department of Education Technologies at the Ministry of Education". And this causes a negative impact on the professional development of school information professionals such as "there are no clear criteria for the right choice of information professionals to attend internal and external courses and conferences, and most of the time are undisclosed by responsible and completely treated with confidentiality" G7. 
Some groups have focused on the fact that there are current challenges in the process of communicating with the department in the directorates and supervisors to discuss the difficulties they face in the field "when discussing difficulties related to the role of the learning resource specialist with the department or supervisors at work and the center. In fact, the matter is always bounced back at attributed to the personality of the learning resource specialists and his ability to prove his/her role, without taking any decision to resolve the problem" G9.

The absence of the learning resource specialists at schools in the first cycle of the basic education

Lack of awareness on the importance and the role of the learning resource specialist in Omani schools may be considered as the main reason for the cultural absence of the importance of the learning resource specialist in schools of the first cycle of basic education, which caused to the low levels of awareness among the Omani students regarding the significance of reading and the creation of a friendly relation with books as a daily routine practice and basic concept among the Omani students and also establishing this in the early stages of education , and also enhancing awareness on the importance of the center of learning resources at school "schools of the first cycle of basic education does not have the learning resource specialist, but his/her duties were assigned to a computer specialist, and this affects negatively on the life of the student and the relationship with the Learning Resource Center" G7.

Group 9 stressed that the presence of the learning resource specialists in the first cycle schools of basic education is a prerequisite for the creation of an integrated Omani personality " the need to have the learning resource specialists available in the schools of the first cycle as it is involved in the most vital age group in which the intellectual character of the student is formed".

\section{Maintenance of hardware and Internet in schools}

Participants in the workshops believe that the Internet at school has a positive role in improving the work of the Learning Resource Center. This is due to some programs that operate with the Internet such as the Unified Index, but most schools suffer from "the weakness of the Internet and lack of its availability in some schools" G6. The study findings also revealed that "the absence of periodic follow-up and maintenance of devices in the Learning Resource Center, and the lack of equipment in the center" G7.

\section{Job Title: LRC Resource Specialist}

All groups from Group1 to Group 9 agreed that the job title should be information professional and this job designation title must be agreed upon in all the institutions of the Sultanate of Oman. The Omani information professional believes that the job title of the profession of information specialists should not change by altering the place where the profession is now functioned currently in Oman. For example, G9 indicated that "Job title gives the impression that the role is attributed to the place of a specialist in learning sources, and the correct concept must be information professional". Conversely, Ma Stahl (2018) found out that librarians in medical education are called on as partners in the classroom, or research collaborators.

\section{Evaluate the work of the information professional}

Some participants in the workshops believe that the assessment mechanism of the information professional in schools should be considered, considering that the mechanism used is not appropriate and may lack credibility "the information professional is evaluated through the number of classes conducted at the center by teachers, the fields and activities that have been 
done at the center, and the number of borrowing books, without paying attention to the degree and level of activation of the information services that center offers"G9. Moreover, Group 6 underlined that" there is no relationship between the activity of the teacher who wishes to implement lesson in the center, however; this is linked to the evaluation of the information professional".

\section{Competencies acquired by the information professional from work}

Workshop participants believe that the practice of their profession as a learning specialist (the information professional) in schools has enhanced their range of skills such as" Public relations, research skills, and partnership"G5. Group 5 added, " the skill of marketing services, dealing with technology, the skill of communicating with others, and ways of dealing with the beneficiary".

\section{Skills needed by the learning resource specialists}

The skills needed by the learning resource specialists are:

\section{Training:}

All groups participating in the workshop agreed that there was a real need for "training to keep updated with the development and they stressed the need to take into account the needs of the learning resource specialist, and the time of holding training courses" G5, 7. Furthermore, Group8 pointed out that " the learning resource specialists need training in technical and managerial issues to reinforce the performance knowledge and the designated duties at the center successfully". As confirmed by the Group2 "the multifunction of training courses in each new field". The Group1 explained that the learning resource specialist in school is in need of training courses in" implementing plans and programs that enhance communication skills and technical innovations in the field".

Some groups also see that there is no standardized professional development program for all the learning resource specialist in the Omani schools. This is left in the hand of the activity of the Directorate General for Education where the learning resource specialist (as known Omani schools) belongs. This may cause the feeling of dissatisfaction and resentfulness with the employee". The imbalance in the preparation of professional development programs for the learning resource specialists is conducted for the 'learning resource specialist', as some governorates did almost annually" G9.

\section{English language:}

The English language may be "a barrier to the development of the learning resource specialists because of the lack of English language"G5. English is often used in most programs that serve information science, so it is an obstacle for the purpose of achieving self-learning to keep up with the new updates in the field of information science. The finding of this research supports results produced by Alkharousi, Jabur, Bouazza and Al-Harrasi (2016), Isfandyari-Moghaddam and Hosseini-Shoar (2014). They found that librarians' skill in the English language was the main factor affecting the use of Web 2.0 applications in Omani and Iranian libraries.

The results of the study revealed that the learning resource specialist in the Department of Information Studies in Arts and social Science college in Sultan Qaboos University focused on" technical services, information management, research and information marketing"G4. Groups also see the need to focus on "practical aspects in involving students in schools and academic libraries "G6, 7, 8, 9. Besides, they believed that the student should be trained in the Department of Information Studies on" practical training in various libraries whether academic or public, and learning resource centers". 
The results of the study revealed that the professional preparation of the information professional in the Department of Information Studies in Arts and social Science college in Sultan Qaboos University lacked of "teaching the information professional students on how to make work plan and mechanism to implement it, as well as there was no clear picture of the functions of the information professional in the LRC. The Department of Information Studies focused on preparing the information professional to work in academic libraries " G1. The groups suggested that "the theoretical material be constantly updated in line with the knowledge developments in information studies"G8. Likewise added "communication skills with others"G9.

\section{SUGGESTIONS TO IMPROVE THE ACTUAL STATUS}

The information professional recommends the necessity "to receive direct support from the supervisors in the information professional career, as well as to give him/her a place in the school community and taking into account the merit of honoring him/her on Teacher's Day. Besides, offering them the opportunity of promotions as compensation for his/her achievements and creations. The information professional must clearly understand the requirements of his/her functions in an orderly manner "G1, 7. It was suggested that "an annual award at the level of the Ministry of Education should be allocated for the best initiative in this field 'LRC' "G7.

All groups agreed that it is necessary to "allocate a special detailed budget for Learning Resource Center". In addition, "perform different broadcasts, participate in library events and read"G1. Participating groups explained that the LRC has the right in the school budget. For example, G4 said that "LRC has the right to benefit from the school budget but in reality, it is under the control of the school administration". This is due to" The 4 lack of awareness in the school's administration on the importance and role of the LRC; despite the fact that the professionals defined the center and its services "G4. It also explained by G5 that the reason for the lack of the financial needs of the Center's requirements may be due to" there is no specified budget item for LRC in the school budget".

The groups also emphasize the importance of involving the learning resource specialist in the "acquisition process "G5. The participants stressed that there are actual problems in the acquisition process, for example, G6 said that "acquisition is not done accordingly to the needs of the center, the subjects and the age levels of the students, and it is provided without taking the opinion of the professional and the senior teachers". Consequently, it causes negative effects, for example; "it has the wrong choice of learning sources such as books, and after provision order is done for the books, a followed letter request the withdrawn of them. In fact, the main acquisition process is central and comes from the Ministry of Education. There is also a weakness in providing the center with electronic materials such as audio and video sources "G6.

It also confirmed that centralized acquisition is caused" failure to respond to the actual needs of schools"G7. Furthermore, Group8 provided an example of the negative effects of the central acquisition "in my school we have been provided with a large number of books, while other schools in far areas have a density of students. It is better to communicate with the learning resource specialist to identify the actual needs. These resources can be used in schools with a high density of students". Group 8 explained their contribution in the acquisition process that will help to "avoid re-provision of the same book collections in the same school whereas there is a lack in schools". 
Participants also stressed the significance of the participation of the learning resource specialist in the field of developing the annual plan of the learning resource centers in Omani schools. For example, Group6 and 7 highlighted that "the learning resource specialist should be involved in the development of the unified annual plan for LRC and participation in decisionmaking". The Group7 clarified that "in the field, there are involvements of human resources which are not used in decision-making and taking part in making plans to improve learning resource centers in Omani schools".

Participants also believe that there is a need of more than one " learning resource specialists in one school, especially those with a high density of students "G4.And the learning resource specialist should be participated in "conferences and forums on information science topics and training programs locally and outside the Sultanate of Participants in the workshops also agreed that the LRC building should be checked and have to be suitable for the services provided at school" some of the learning centers in schools are unfit. Two classrooms are put together to be a center. So it is a small place and it unsuitable for the service. Also, the location of the center in some schools is inappropriate"G6. As indicated by Group8 "the division of the Learning Resource Center does not suit the services or objectives that the Center seeks to achieve. We need, for example, a private hall to achieve the service of the curriculum, a special hall for works of art, and the main hall containing books and computers".

\section{CONCLUSION}

According to the quantitative part, the results of the analysis showed a weak correlation between educational programs and work practices, especially in tasks requiring specialized skills and competencies. This phenomenon is interpreted by the centralization procedures of the Ministry of Education in terms of the collection building and organization. This practice isolates the professionals from performing their actual role and ignore the diversity of the actual users' needs. Responded professionals confirmed that most of these activities have been done beyond their professional roles. Thus, the results ensure the unclear image of the profession.

The qualitative findings showed that school staff view to the information professionals is negative and this view affected their works and improvement. The weakness of LRC regulation, lack communication between the information professional and the concerned parties, the absence of using correct techniques to evaluate the work of the information professional is factors hindered the development of professional career and help to the emergence of this negative view of the profession in Omani schools. The Department of Information Studies in Arts and social Science college in Sultan Qaboos University need to focus on practical aspects in various libraries whether academic or public and learning resource centers, besides; English language skills. The information professional recommends the significance of the participation of the learning resource specialist in the field of developing the annual plan of the learning resource centers in Omani schools.

\section{RECOMMENDATIONS}

Accordingly, the study suggests achieving effective communication between the professional educational institutions and decision-makers, employers, and related discipline in colleges such as management, knowledge economy and information systems to discuss the integrated knowledge and competencies the professionals need to acquire. The objective of such a meeting is to reach the basic competencies that respond to the requirements of the profession and the needs of the job market. These meetings also will contribute to the characterization and practice of the profession in order to achieve the participation of professionals as partners in the educational process and to ensure the characteristics of interdisciplinarity that the 
profession is composed of. The following map is suggested for more discussion in other researches.

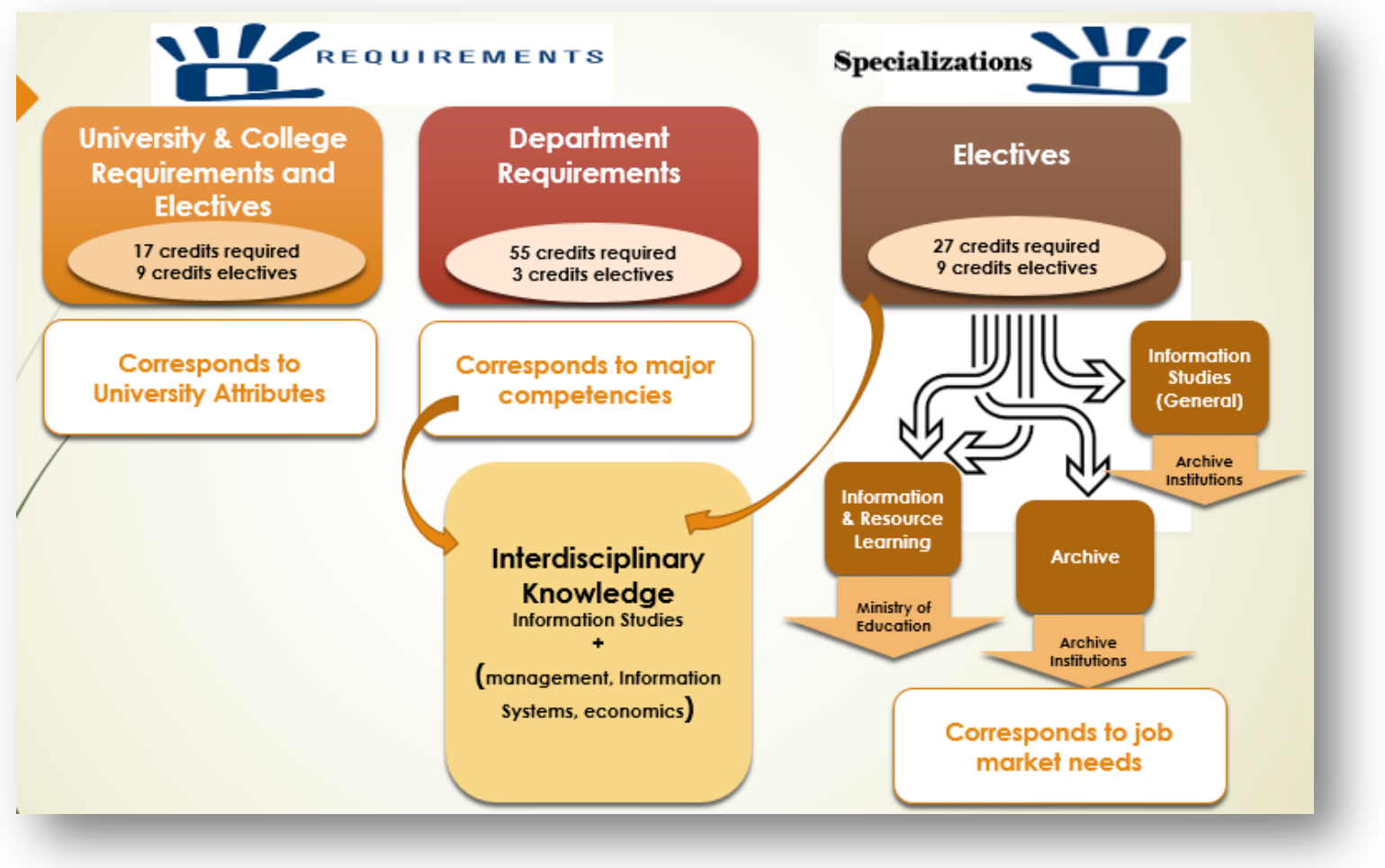

\section{References}

Alkarousi, R. Jabur, N. Bouazza, A. and Al-Harrasi, N. (2016). "Factors affecting the implementation of Web 2.0 applications in Omani Academic Libraries", Electronic Library, Vol.34 Issue2, P332-351

Athey, T.R. and Orth, M.S. (1999), "Emerging competency methods for the future", Human Resource Management, Vol. 38 No. 3, pp. 215-226. http://timatheyphd.com/wpcontent/uploads/2014/08/EmergingCompetencyMethodsForTheFuture TAtheyPhD.pdf

American Association of Law Libraries (2001), "Competencies of law librarianship", American Association of Law Libraries. Retrieved from: https://www.aallnet.org/mm/Leadership-

Governance/policies/PublicPolicies/competencies.html

ARMA International (2007), Records and Information Management Core Competencies, ARMA International. Retrieved from: http://armannj.org/content.php?page=ARMA Educational Opportunities

Association of Canadian Archivists (2017), "Competencies for archivists \& records managers", Association of Canadian Archivists. Retrieved from: http://www.mlanet.org/p/cm/ld/fid=1217

Australian Library and Information Association. (2014) Future of the library and information science profession. https://www.alia.org.au/sites/default/files/documents/advocacy/ALIA-Future-of-the-Profession-ALL.pdf

Canadian General Standards Board (2009), Competencies of the Federal Government Information Management Community, Canadian Government Standards Board, Gatineau. Retrieved from:

http://publications.gc.ca/collections/collection 2017/ongc-cgsb/P29-5-192-2-2009-eng.pdf

Ennis, M.R. (2008), Competency Models: A Review of the Literature and the Role of the Employment and Training Administration (ETA), retrieved from https://goo.gl/ZphgM

Ferreira, F. \& others (2007) Information professionals in Brazil: core competencies and professional development. IR Information Research. Vol. 12 (2). Retrieved from: http://www.informationr.net/ir/12-2/paper299.html

Fraser-Arnott, M. (2017). "Competencies for information specialists in emerging roles." Library

Management, 38(1), 65-76. doi:10.1108/lm-09-2016-0074.

http://ezproxysrv.squ.edu.om:2253/doi/pdfplus/10.1108/LM-09-2016-0074 
competency-based education in the health professions for improving global health", Human Resources for Health, Vol. 10 No. 43, pp. 1-7. https://human-resources-health.biomedcentral.com/articles/10.1186/14784491-10-43

Hashim, L. \& Mokhtar, N.H. (2012) Preparing New Era Librarians and Information Professionals: Trends and Issues. International Journal of Humanities and Social Science. Vol. 2 No. 7. http://www.ijhssnet.com/journals/Vol_2_No_7_April_2012/16.pdf

Isfandyari-Moghaddam, A. \& Hosseini-Shoar, M. (2014), "Factors affecting Web 2.0 adoption: a case study", Program: electronic library and information systems, Vol. 48, No.1, pp.2-15

Kang, Y. and Ritzhaupt, A.D. (2015), "A job announcement analysis of educational technology professional positions: knowledge, skills, and abilities", Journal of Educational Technology Systems, Vol. 43 No. 3, pp. 231-256. http://www.aritzhaupt.com/eprofessional/papers/2015/KangRitzhaupt.pdf

Ley, T. and Albert, D. (2003), "Identifying employee competencies in dynamic work domains: methodological considerations and a case study", Journal of Universal Computer Science, Vol. 9 No. 12, pp. 1500-1518. http://www.jucs.org/jucs 9 12/identifying_employee competencies in/Ley T.pdf

Library of Congress (2011), FLICC Competencies for Federal Librarians, Library of Congress, Washington, DC, available at: https://www.loc.gov/flicc/publications/Lib_Compt/2011/2011Competencies.pdf

Ma, L. and Stahl, L. (2018). "Emerging roles of health information professionals for library and information science curriculum development: a scoping review", Journal of the Medical Library Association, Vol 106, No 4, PP.432-444.

Markaz al-Imarat li-al-Dirasat wa-al-Buhuth, a. (2013). Information Technology and Future of Education in the United Arab Emirates. Abu Dhabi: ECSSR. https://goo.gl/yvPzjp

Moore, L.L. and Rudd, R.D. (2004), "Leadership skills and competencies for extension state directors and administrators", Journal of Agricultural Education, Vol. 45 No. 3, pp. 22-33.

http://citeseerx.ist.psu.edu/viewdoc/download?doi=10.1.1.485.5611\&rep=rep1\&type=pdf

Ruddock, B. (2012) Alternative careers for new library \& information professionals. Retrieved from.https://www.slideshare.net/bethanar/alternative-careers-for-new-library-information-professionals

Special Libraries Association (SLA) (2016), "Competencies for information professionals of the 21st century", Special Libraries Association (SLA). Retrieved from: https://www.sla.org/about-sla/competencies/

Stark, M. (2005) Creating a Positive Professional Image. Research Ideas, Harvard Business School. Retrieved from: https://hbswk.hbs.edu/item/creating-a-positive-professional-image 